\title{
Enhancing Freehand Sketching in Industrial Design: Description and Implementation of a Drawing Methodology for More Effective Representations
}

\author{
Francisco Felip, ${ }^{1}$ Jaume I University Universitat Jaume I, Spain \\ José Luis Navarro, Jaume I University Universitat Jaume I, Spain
}

\begin{abstract}
Freehand sketching is an important part of the design process that allows one to communicate in a quick and gestural way the first ideas about new concepts and is a medium for graphic thinking. It is important for architects and designers because it is a mechanism of representation, conceptualization, and abstraction for the communication between the creators and their audience. All academic courses related to industrial design include subjects aimed at acquiring skills in the use of manual tools of graphic representation, recognizing their importance in the integral training of the designer. However, sometimes the methodologies implemented in some subjects fail to develop adequately the skills of the students, who finish their studies with shortcomings in the field of graphic representation. This paper describes exercises that are part of a methodology designed to help students of industrial design acquire the skills to make an agile and effective use of freehand sketching. Through different uses of the elements of formal expression, the exercises address topics such as shape analysis, composition, light, color, and descriptive illustration. The methodology is applied experimentally in a subject of the bachelor's degree in industrial design and product development engineering at Jaume 1 University Universitat Jaume I, introducing the students to different instruments and techniques of sketching and proposing various enriching ways of direct observation of the objectual reality that surrounds them. The paper concludes by evaluating the positive impact of the implemented methodology.
\end{abstract}

Keywords: Freehand Sketching, Drawing Techniques, Industrial Design Education

Introduction: Drawing as a Tool for Conceptualization and Communication in Design [Please shorten this heading to-one line, if possible.]

$\mathrm{M}$

anual sketching acquires a significant relevance in the field of design by allowing communicating in a gestural and fast way the first ideas about new concepts. The line, the composition, the color, the perspective, or the chiaroscuro, when they are in correct synergy, give form to an effective graphic discourse capable of visually channeling the work of the designer and favoring the understanding of that represented. Travis (2014) defends the need to practice these basic components of manual sketching in disciplines such as architecture and space design as a tool that helps to see and understand what is perceived, but given that they share many of their creative approaches, it can be said that its practice is also necessary for the discipline of industrial design. Freehand sketching, like the construction of models, is an activity closely related to the design process that helps the designer become familiar with the geometry of objects, allowing her to better understand the space around us and the shapes that in it are found (Carnevale 2015) while fostering creativity (Yang and Cham 2007) and the development of eye-mind-hand coordination (Eggermont et al. 2004).

The practice of drawing leads to the practice of graphic thinking (Goldschmidt 1991), important for architects and designers as a mechanism of representation, conceptualization, and abstraction for communication between the creator and his or her audience. In this sense, Lasseal (2001)_[Please add this source to the reference list.]points out that to get to practice this graphif

${ }^{1}$ Corresponding Author: Francisco Felip, Avda. Vicent Sos Baynat s/n, Department of Industrial Systems Engineering and Design, Jaume I UniversityUniversitat Jaume I, Castellón de la Plana, 12071, Spain. email: ffelip@uji.es 
thinking previously is necessary to enhance the acquisition of perceptual skills and develop manual graphic skills. Thus, studio drawings can be considered a medium for graphic thinking, playing a prominent role in any design work process (Herbert 1988).

Freehand sketching is a part of the cognitive process used by designers in problem solving (Ullman, Wood, and Craig 1990), making it an important part of the design process. But this process, although it requires the learning of certain technical skills, is more complex and requires a creative mind: it is possible to draw without designing but not to design without drawing. Therefore, we can assume that the teaching of freehand sketching as a project tool to give shape to new ideas is essential for the training process of the current industrial designers.

\section{Drawing in University Teaching of Industrial Design: A Case Study}

All university degrees related to industrial design include in their curricula subjects designed to acquire skills in the use of graphic representation manual tools, recognizing their importance for an integral training of the designer. However, as we have been able to verify in our classes in past courses, the methodologies sometimes fail to develop adequately the skills of the student, who finishes the degree with shortcomings in the field of graphic representation. This is the case of the bachelor's degree in industrial design and product development engineering at Jaume I University Universitat Jaume I, which has been used as a case study to develop and experiment with the methodology presented in this paper.

\section{Description and Context}

The course subject [course?] "Artistic Expression II" is one of the subjects taught from September to December in the second year of the four-year bachelor's degree in industrial design and product development engineering. Its main objective is to train students in new techniques of graphic representation and improve their skills in freehand sketching, complementing the knowledge acquired in the subject "Artistic Expression I," taught in the first year, making drawing a means of expression to represent effectively the shape of objects. The acquisition of certain skills in this subject is necessary to contextualize face [contextualize?] correctly the work in other subjects of the degree directed to the conceptualization of new products, taught in the second semester ("Modelmaking Workshop") or in the following courses ("Product Presentation" and "Product Design Prototyping Workshop"), where the graphic representation of concepts about new products is part of the design process and helps to plan the subsequent physical construction of models.

The methodology used in the subject has always been very practical. It addresses issues such as composition and shape analysis, light, volume, and formal expressivity (line, stroke, flat ink, chiaroscuro, and techniques of artistic expression and presentation); color (theory, perception, semantics, and symbology of colors and texture of industrial product); descriptive illustration (human figure and its relation to objects, proportion, stylization, and synthesis); and architectural space (intuitive representation of perspectives). However, it has been observed that after completing the course the students do not apply this knowledge in subsequent courses, so it seems that the skills have not been correctly assimilated and, therefore, the methodology should be revised.

\section{Methodology and Detection of Shortcomings}

During past courses, at the end of this subject it was observed that the students had many difficulties in drawing ideas, concepts, and, in short, everything they did not see, and they did not know how to effectively represent it visually. Consequently, when presenting their ideas about new products, students used to prefer verbal explanations to freehand sketching, which in any case was limited to mere two-dimensional representations, even though the represented products 
had a three-dimensional nature and should be represented by some kind of perspective to be better understood.

Some of the causes of this lack of ability to use freehand sketching fluently to represent new ideas are due to a methodological approach too focused on copying and tracing photographs of objects to interpret them graphically later instead of drawing the real objects by looking directly at them. By directly influencing our understanding of space, observing our environment and familiarizing ourselves with its different spatial depths helps us to learn to represent and interpret in a graphic way the complex and varied object geometry that surrounds us. Consequently, learning how to interpret and represent on paper a volume observed in real space helps to represent other similar volumes when they cannot be seen, giving the industrial designer powerful tools to represent fictitious geometries of new conceptual designs. In addition to learning to improve observational skills, to achieve an adequate skill in freehand sketching, it is necessary to practice it continuously over time, introducing the manual drawing as an inseparable part of each design project that students face (Dong, Cifter, and Fan 2013). Trying to find a solution to the difficulties of the students in the use of freehand sketching is what has motivated to propose a different learning methodology in this subject.

\section{Research Aim}

The purpose of this work is to show and analyze the result of implementing a methodology designed to help the students of Industrial Design Degrees to acquire skills to make an agile and effective use of freehand sketching, abandoning the learning of three-dimensional objects through the mere copy or trace of their two-dimensional images. The methodology, applied in the subject "Artistic Expression II" of the bachelor's degree in industrial design and product development engineering at Jaume I UniversityUniversitat Jaume I, presents several exercises that implement two strategies: introduce students to different instruments and techniques of sketching and get them to practice direct observation of the objectual reality that surrounds them in a more enriching way, learning to interpret correctly the volumes in space to be able to represent effectively other imagined forms for the design of new products.

The main hypotheses of this study are as follows:

- H1: "Observing industrial objects helps students to understand them and can help to represent them in a more clear way, even if they're not in sight."

- H2: "Knowing different drawing techniques helps students to represent an idea more effectively."

To test the hypothesis, two research questions have been formulated:

- Q1: "Does habituating students to observe familiar industrial products as well as manipulating and experimenting them in a tactile manner help them to generate mental images closer to objectual reality?"

- Q2: "Does practicing different drawing techniques for quick representation help students to choose the most appropriate in each occasion?"

\section{Designing an Appropriate Methodology}

Creating a methodology that is effective means first knowing the previous training of the students to identify their weaknesses and strengths. Afterwards, one should identify and understand the competences of the subject, design a series of exercises to achieve them according to the duration of the subject, and create some rubrics to be able to evaluate them in a homogeneous and objective manner. 


\section{Characteristics of Students}

At the beginning of the subject, it is necessary to carry out an anonymous and voluntary survey with the intention to learn more about the students and identify possible characteristics that could influence the development of learning during the course, in case it is necessary to better adjust the contents and the schedule of activities of the subject. In this survey, six questions were asked:

1. Their previous training in high school

2. The perception of the importance they attributed to the subject "Artistic Expression II" for their training as industrial designers (assessing it on a ten-point scale)

3. Their skill level in subjects related to artistic or graphic expression before starting the degree (assessing it on a ten-point scale)

4. Their skill level in subjects related to artistic or graphic expression before beginning the subject "Artistic Expression II" (assessing it on a ten-point scale).

5. Their interest in drawing and the use of artistic expression techniques in their daily life (assessing it on a ten-point scale).

6. The affinity they feel for each of the five branches related to design, from higher to lower technical nature: A) engineering / industrial technology, B) engineering / product design, C) product design / graphic design, D) design / plastic arts, E) fine arts and F) other branches.

Of the eighty-five enrolled students, seventy-two answered the survey. The first answer revealed that fifty-five students came from technical high schools, four from artistic high schools, fure-four from social high schools, four from a bachelor's degree in industrial design (Latin America), and five from other high schools. Most of them have received previous technical training, like that offered by the degree in industrial design that they are studying (Figure 1).

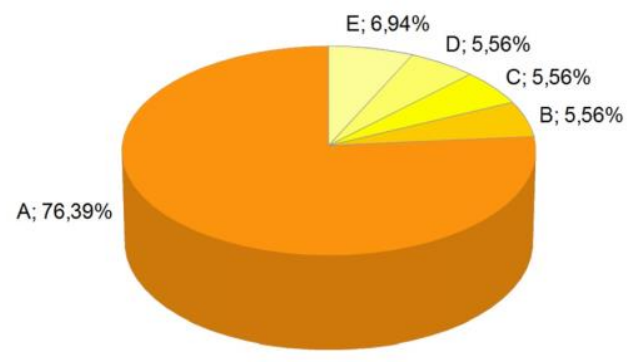

Figure 1: Previous Training: A) Technical High Schools, B) Artistic High Schools, C) Social High Schools, D) Bachelor Degree in Industrial Design (Latin America), and E) Other High Schools Source: Felip and Navarro 2018

The answers to the second question revealed that the average perception of the importance of the subject was 8.55 points out of 10, with 6 points ( 2 students) being detected as the lowest value and 10 points (15 students) being the highest value. In the third and fourth questions, the students stated that they had an average skill of 4.50 points out of 10 in subjects of plastic expression before beginning the degree, and of 6.61 points right at the beginning of this subject, which indicates that the perception of their skills improved 2.11 points $(46.89 \%)$ during the first year of the degree. The fifth question revealed a moderately significant interest in drawing outside the academic field, standing at 6.86 points out of 10 , which indicated a good predisposition among students toward the use of plastic expression tools in their daily lives. The answers to the sixth question indicated that their main affinities were to engineering / product 
design and product design / graphic design, followed by engineering / industrial technology, design / plastic arts, fine arts, and, finally, other branches of design (Figure 2).

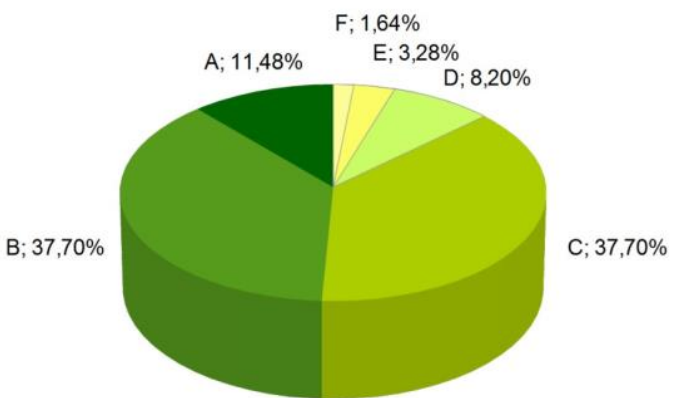

Figure 2: Affinity of "Artistic Expression II" Students toward the Branches Related to Design:

A) Engineering / Industrial Technology, B) Engineering / Product Design, C) Product Design / Graphic Design,

D) Design / Plastic Arts, E) Fine Arts, and F) Other Branches

Source: Felip and Navarro 2018

The answers to this initial survey revealed that students considered artistic training moderately important for the profession of designer (6.86 points out of 10), although most of the students had a strong technical training prior to this degree $(76.39 \%)$ and a natural trend oriented toward design branches with an average technical level $(75.4 \%)$. The students declared that they had low artistic expression skills at the beginning of the degree but acknowledged that they had improved after finishing the first year. So, if the new exercises are correctly adapted to their initial abilities, it is possible to achieve an improvement in their skills at the end of this course.

\section{Subject Competences}

The competences that the students had to achieve at the end of this subject were defined in the curriculum of the degree, so they were used as a starting point for the preparation of course exercises:

- $\mathrm{C} 1$ : Creativity and innovation in the field of design

- $\quad$ C2: Being able to communicate effectively orally and in writing, writing reports and all the written and graphic documentation necessary to communicate ideas and projects.

- C3: Being able to handle techniques and tools for artistic expression and representation

- C4: Motivation for quality 


\section{Preparation of Exercises}

The exercises were designed to acquire certain skills that would help students to develop the four competences of the subject, proposing a working methodology with a double purpose: to practice different ways of observing and understanding reality and to practice different techniques of representation. Taking as a premise that in learning on how to represent a new product it is necessary to know first those similar that act as referents, students are provided with several industrial products that act as reference models (small appliances, vehicles, utensils, toys, packaging, and urban and domestic furniture), training the perception of shapes from direct observation and from tactile manipulation. The main idea is to present a small challenge with each exercise to practice different ways of approaching the drawing of industrial objects without falling into repetition and to maintain high student motivation and interest. The various exercises were distributed in thirteen groups, described in detail below.

Group 1 was analysis and interpretation of geometric volumes (1). Through six conceptual experimentation practices $(1 \mathrm{~A}-1 \mathrm{~F})$, we tried to reactivate the knowledge acquired in the previous subject. This type of practices also serves to disinhibit the ability to respond to the new problems of artistic expression that arise.

Table 1: Breakdown of Exercises (Group 1)

\begin{tabular}{|c|c|c|c|c|c|}
\hline \multicolumn{4}{|c|}{$\begin{array}{c}\text { Competences to Be } \\
\text { Achieved }\end{array}$} & \multirow{2}{*}{$\begin{array}{l}\text { Exercises to Achieve Competences: } \\
\text { Description and / or Procedure }\end{array}$} & \multirow{2}{*}{ Implemented Technique } \\
\hline C1 & $\mathbf{C 2}$ & C3 & $\mathrm{C4}$ & & \\
\hline & & $\bullet$ & & $\begin{array}{l}\text { 1A. Interpretation of a mental image from a descriptive } \\
\text { narration with geometric volumes }\end{array}$ & $\begin{array}{l}\text { Linear perspective drawing } \\
\text { with } 2 \mathrm{~B} \text { pencil on paper. DIN } \\
\text { A4. }\end{array}$ \\
\hline & & $\bullet$ & & $\begin{array}{l}\text { 1B. Formal reproduction through tactile experiences } \\
\text { (several elements) }\end{array}$ & $\begin{array}{l}\text { Linear perspective drawing } \\
\text { with } 2 \mathrm{~B} \text { pencil on paper. DIN } \\
\text { A4. }\end{array}$ \\
\hline & & $\bullet$ & & $\begin{array}{l}\text { 1C. Interpretation of the cylindrical volumes of the } \\
\text { proposed model using prismatic shapes }\end{array}$ & $\begin{array}{l}\text { Linear perspective drawing } \\
\text { with } 2 \mathrm{~B} \text { pencil on paper. DIN } \\
\text { A4. }\end{array}$ \\
\hline & & $\bullet$ & & $\begin{array}{l}\text { 1D. Conceptual interpretation of the practice } 1 \mathrm{C} \text { from a } \\
\text { different point of view without observing the analyzed } \\
\text { model }\end{array}$ & $\begin{array}{l}\text { Linear perspective drawing } \\
\text { with ball pen on paper. DIN } \\
\text { A4. }\end{array}$ \\
\hline & & $\bullet$ & $\bullet$ & 1E. Chiaroscuro perspective drawing of the model & 2B pencil on paper. DIN A4. \\
\hline & & $\bullet$ & $\bullet$ & 1F. Chiaroscuro pointillist interpretation from practice $1 \mathrm{E}$. & $\begin{array}{l}\text { Ball pen or fine-tip marker on } \\
\text { paper. Blue or black color. } \\
\text { DIN A4. }\end{array}$ \\
\hline
\end{tabular}

Group 2 was analysis and interpretation of geometric volumes (2). Through several practices, the tactile perception of the volume or the shape that is perceived using the hands (practices 2A and 2B) was experienced, with students practicing both with geometric and organic shapes. After interpreting a model configured with cylindrical shapes and straight planes by means of rapid sketching (practices 2C and 2D), the interpretation of the proposed model was requested by imagining and drawing a nonexistent membrane to give the sensation of continuity between the different volumes, as if it were a slightly tightened skin on a structure, first through line $(2 \mathrm{E})$ and then through chiaroscuro to enhance the volumetric sensation $(2 \mathrm{~F})$. These are topological surfaces for students to discover that things are not only as they are seen, but can be coated with an external form of organic nature. 
FELIP AND NAVARRO: ENHANCING FREEHAND SKETCHING IN INDUSTRIAL DESIGN

Table 2: Breakdown of Exercises (Group 2)

\begin{tabular}{|c|c|c|c|c|c|}
\hline \multicolumn{4}{|c|}{$\begin{array}{c}\text { Competences to Be } \\
\text { Achieved }\end{array}$} & \multirow{2}{*}{$\begin{array}{c}\text { Exercises to Achieve Competences: } \\
\text { Description and / or Procedure }\end{array}$} & \multirow{2}{*}{ Implemented Technique } \\
\hline $\mathrm{C1}$ & $\mathrm{C} 2$ & C3 & C4 & & \\
\hline & & $\bullet$ & & $\begin{array}{l}\text { 2A. Shape recognition by tactile experiences (geometric } \\
\text { shapes). }\end{array}$ & $\begin{array}{l}\text { Linear perspective drawing } \\
\text { with } 2 \mathrm{~B} \text { pencil on paper. DIN } \\
\text { A4. }\end{array}$ \\
\hline & & $\bullet$ & & $\begin{array}{l}\text { 2B. Formal reproduction through tactile experiences } \\
\text { (organic shapes). }\end{array}$ & $\begin{array}{l}\text { Linear perspective drawing with } \\
\text { 2B pencil or ball pen, on paper. } \\
\text { DIN A4. }\end{array}$ \\
\hline & & $\bullet$ & & 2C. Rapid sketching of the proposed model. & 2B pencil on paper. DIN A4. \\
\hline & & $\bullet$ & & $\begin{array}{l}\text { 2D. Rapid sketching of the proposed model from another } \\
\text { point of view }\end{array}$ & $\begin{array}{l}\text { BallpenBall pen on paper. DIN } \\
\text { A4. }\end{array}$ \\
\hline & & $\bullet$ & & $\begin{array}{l}2 \mathrm{E} \text {. Interpret the cylindrical volumes of the model } \\
\text { analyzed in practice } 2 \mathrm{D} \text { through membranes or } \\
\text { topological surfaces. }\end{array}$ & $\begin{array}{l}\text { Linear perspective drawing } \\
\text { with } 2 \mathrm{~B} \text { pencil on paper. DIN } \\
\text { A4. }\end{array}$ \\
\hline & & $\bullet$ & & $\begin{array}{l}2 \mathrm{~F} \text {. Interpret the model conceptualized in practice } 2 \mathrm{E} \\
\text { using monochromatic chiaroscuro. }\end{array}$ & $\begin{array}{l}\text { Technique limited to pencil, } \\
\text { charcoal or black color } \\
\text { ballpenball pen on paper. DIN } \\
\text { A4. }\end{array}$ \\
\hline
\end{tabular}

Group 3 was an analysis of everyday objects: rocker toy. Through four practices (3A-3D), we sought to understand the product observed from different points of view, representing and interpreting it with different graphic techniques.

Table 3: Breakdown of Exercises (Group 3)

\begin{tabular}{|c|c|c|c|c|c|}
\hline \multicolumn{4}{|c|}{$\begin{array}{l}\text { Competences to Be } \\
\text { Achieved }\end{array}$} & \multirow{2}{*}{$\begin{array}{l}\text { Exercises to Achieve Competences: } \\
\text { Description and / or Procedure }\end{array}$} & \multirow{2}{*}{ Implemented Technique } \\
\hline C1 & $\mathrm{C2}$ & C3 & $\mathrm{C4}$ & & \\
\hline & & $\bullet$ & & 3A. Linear perspective drawing of the proposed model & 2B pencil on paper. DIN A4. \\
\hline & & $\bullet$ & & $\begin{array}{l}\text { 3B. Linear perspective drawing of the proposed model from } \\
\text { another point of view }\end{array}$ & 2B pencil on paper. DIN A4. \\
\hline & & $\bullet$ & $\bullet$ & $\begin{array}{l}\text { 3C. Interpretation of a new point of view of the model by } \\
\text { chiaroscuro of linear traces }\end{array}$ & $\begin{array}{l}\text { Fine-tip marker pen, pen and } \\
\text { ink, stylographs, or other } \\
\text { permanent means of black, } \\
\text { brown, or blue color, on paper. } \\
\text { DIN A4. }\end{array}$ \\
\hline & & $\bullet$ & $\bullet$ & $\begin{array}{l}\text { 3D. Free chromatic interpretation of one of the viewpoints } \\
\text { studied in practices } 3 \mathrm{~A}-\mathrm{B} \text {, using visual textures (dots, } \\
\text { traces, etc.) or using plain colors }\end{array}$ & $\begin{array}{l}\text { Marker pens, colored inks or } \\
\text { tempera paint on paper. DIN } \\
\text { A4. }\end{array}$ \\
\hline
\end{tabular}

Group 4 was analysis of everyday objects: taps. By means of five practices ( $4 \mathrm{~A}-4 \mathrm{E})$ students were expected to familiarize themselves with the formal identity of an industrial product, common in all households, learning its mode of operation through manipulation, direct observation of its volume and the representation of its parts. 


\section{THE INTERNATHONAL JOURNAL OF DESIGN EDUCATION}

Table 4: Breakdown of Exercises (Group 4)

\begin{tabular}{|c|c|c|c|c|c|}
\hline \multicolumn{4}{|c|}{$\begin{array}{c}\text { Competences to Be } \\
\text { Achieved }\end{array}$} & \multirow{2}{*}{$\begin{array}{l}\text { Exercises to Achieve Competences: } \\
\text { Description and / or Procedure }\end{array}$} & \multirow{2}{*}{ Implemented Technique } \\
\hline C1 & $\mathrm{C} 2$ & C3 & C4 & & \\
\hline & & $\bullet$ & $\bullet$ & $\begin{array}{l}\text { 4A. Sketching a tap considering its volume and not its } \\
\text { materiality }\end{array}$ & $\begin{array}{l}\text { Linear perspective drawing } \\
\text { with } 2 \text { B pencil on paper }(2 \\
\text { different points of view). DIN } \\
\text { A4. }\end{array}$ \\
\hline & & $\bullet$ & $\bullet$ & $\begin{array}{l}\text { 4B. Linear drawing of the same model as the one of practice } \\
\text { 4A, from another point of view }\end{array}$ & $\begin{array}{l}\text { BallpenBall pen on paper. DIN } \\
\text { A4. }\end{array}$ \\
\hline & $\bullet$ & $\bullet$ & $\bullet$ & $\begin{array}{l}\text { 4C. Blurred monochrome chiaroscuro of a different model. } \\
\text { It is to interpret the model as if it were non-metallic or } \\
\text { reflective, but like a matte material. }\end{array}$ & $\begin{array}{l}\text { 2B pencil on thick paper }(120- \\
130 \mathrm{~g})\end{array}$ \\
\hline & & $\bullet$ & $\bullet$ & $\begin{array}{l}\text { 4D. Design and draw a new tap of different function (bath, } \\
\text { bidet, kitchen, etc.) based on the same formal pattern as the } \\
\text { tap of practice } 4 \mathrm{~B} \text {. The tap is designed to look like part of a } \\
\text { product family. }\end{array}$ & $\begin{array}{l}\text { 2B pencil or ball pen on paper. } \\
\text { DIN A4. }\end{array}$ \\
\hline & & $\bullet$ & $\bullet$ & $\begin{array}{l}\text { 4E. Monochromatic interpretation of a new point of view of } \\
\text { the tap analyzed in practice } 4 \mathrm{C} \text {, using line and a single flat } \\
\text { ink. }\end{array}$ & $\begin{array}{l}\text { Marker pens, colored inks, or } \\
\text { tempera paint on paper. DIN } \\
\text { A4. }\end{array}$ \\
\hline
\end{tabular}

Group 5 was an analysis of everyday objects: household packaging. Through four manipulation and direct observation practices $(5 \mathrm{~A}-5 \mathrm{D})$ students were expected to understand that the product volumetry is directly related to their ergonomic features and to learn to propose improvements through drawing.

Table 5: Breakdown of Exercises (Group 5)

\begin{tabular}{|c|c|c|c|c|c|}
\hline \multicolumn{4}{|c|}{$\begin{array}{l}\text { Competences to Be } \\
\text { Achieved }\end{array}$} & \multirow{2}{*}{$\begin{array}{l}\text { Exercises to Achieve Competences: } \\
\text { Description and / or Procedure }\end{array}$} & \multirow{2}{*}{ Implemented Technique } \\
\hline C1 & $\mathrm{C2}$ & C3 & C4 & & \\
\hline & & $\bullet$ & $\bullet$ & $\begin{array}{l}\text { 5A. Quick sketching of one of the proposed models, in } \\
\text { perspective. }\end{array}$ & $\begin{array}{l}\text { BallpenBall pen on paper. } \\
\text { Blue or black color. DIN A4. }\end{array}$ \\
\hline & & $\bullet$ & $\bullet$ & $\begin{array}{l}\text { 5B. Ergonomic studies: drawing the hand in two different } \\
\text { positions using schematic sketching-. }\end{array}$ & $\begin{array}{l}\text { 2B pencil or ballpenball pen } \\
\text { on paper. DIN A4. }\end{array}$ \\
\hline & & $\bullet$ & $\bullet$ & $\begin{array}{l}\text { 5C. Ergonomic study of the object. Linear drawing of the } \\
\text { object in perspective. Drawing the hand grasping the } \\
\text { object from another point of view. }\end{array}$ & $\begin{array}{l}\text { Ball pen on paper. Blue or } \\
\text { black color. DIN A4. }\end{array}$ \\
\hline & & $\bullet$ & $\bullet$ & $\begin{array}{l}\text { 5D. Based on practice } 5 \mathrm{C} \text { : new drawing in which the } \\
\text { contour line of the object is enhanced more than the } \\
\text { contour of the hand in order to enhance the visual } \\
\text { difference. }\end{array}$ & $\begin{array}{l}\text { Fine-tip, medium-tip or thick- } \\
\text { tip marker pens on paper. DIN } \\
\text { A4. }\end{array}$ \\
\hline
\end{tabular}


Group 6 was an analysis of everyday objects: electrical appliances. Through four practices (6A-6D), students had to familiarize themselves with the formal identity of various small electrical appliances. After analysis and perspective representation of one of the provided models (6A), it was necessary to imagine and propose breakdown exploded [different word?] views tp become familiar with the shape and function of the components of an industrial product (6B). Next, the chromatic interpretation was proposed as a resource to represent the volumetry of a product without using perspective after having made a linear graphic image of the elevation of one of the models (6C and 6D).

Table 6: Breakdown of Exercises (Group 6)

\begin{tabular}{|c|c|c|c|c|c|}
\hline \multicolumn{4}{|c|}{$\begin{array}{c}\text { Competences to Be } \\
\text { Achieved }\end{array}$} & \multirow{2}{*}{$\begin{array}{l}\text { Exercises to Achieve Competences: } \\
\text { Description and / or Procedure }\end{array}$} & \multirow{2}{*}{ Implemented Technique } \\
\hline C1 & $\mathrm{C2}$ & C3 & $\mathrm{C4}$ & & \\
\hline & & $\bullet$ & $\bullet$ & $\begin{array}{l}\text { 6A. Line drawing in perspective of a small typical } \\
\text { household appliance (blender, electric coffee maker, } \\
\text { juicer, etc.) }\end{array}$ & $\begin{array}{l}\text { Ball pen on paper. Blue or } \\
\text { black color. DIN A4. }\end{array}$ \\
\hline & $\bullet$ & $\bullet$ & $\bullet$ & $\begin{array}{l}\text { 6B. Line drawing in perspective of exploded view of the } \\
\text { model studied in practice } 6 \mathrm{~A}\end{array}$ & 2B pencil on paper. DIN A4. \\
\hline & & $\bullet$ & $\bullet$ & $\begin{array}{l}6 \mathrm{C} \text {. Sketch of a single orthogonal projection (the elevation } \\
\text { or profile) as the basic representation of a product }\end{array}$ & $\begin{array}{l}\text { Marker pen or ball pen on } \\
\text { paper. Black color. DIN A4. }\end{array}$ \\
\hline & & $\bullet$ & • & $\begin{array}{l}\text { 6D. Chromatic interpretation of the } 6 \mathrm{C} \text { practice sketch to } \\
\text { generate volumetric sensation in the represented image }\end{array}$ & $\begin{array}{l}\text { Free technique on paper. } \\
\text { DIN A4. }\end{array}$ \\
\hline
\end{tabular}

Group 7 was an analysis of everyday objects: toys. Two fast-paced sketching practices were proposed to reinforce the formal uptake of the observed models, dispensing with superfluous details through a synthesis that served to exercise a more spontaneous expression of perceived objects (7A and 7B). Next, a formal redesign of one of the toys (7C) and its interpretation by various graphic techniques (7D) was carried out.

Table 7: Breakdown of Exercises (Group 7)

\begin{tabular}{|c|c|c|c|c|c|}
\hline \multicolumn{4}{|c|}{$\begin{array}{c}\text { Competences to Be } \\
\text { Achieved }\end{array}$} & \multirow{2}{*}{$\begin{array}{l}\text { Exercises to Achieve Competences: } \\
\text { Description and / or Procedure }\end{array}$} & \multirow{2}{*}{ Implemented Technique } \\
\hline C1 & $\mathrm{C2}$ & $\mathrm{C3}$ & $\mathrm{C4}$ & & \\
\hline & & $\bullet$ & $\bullet$ & $\begin{array}{l}\text { 7A. Quick perspective sketching of one of the proposed } \\
\text { models }\end{array}$ & $\begin{array}{l}\text { Ball pen on paper. Blue or } \\
\text { black color. DIN A4. }\end{array}$ \\
\hline & & $\bullet$ & $\bullet$ & $\begin{array}{l}\text { 7B. Quick perspective sketching of another of the } \\
\text { proposed models }\end{array}$ & $\begin{array}{l}\text { Ball pen on paper. Blue or } \\
\text { black color. DIN A4. }\end{array}$ \\
\hline \multirow[t]{2}{*}{$\bullet$} & & $\bullet$ & $\bullet$ & $\begin{array}{l}\text { 7C. Redesign of one of the models studied, through } \\
\text { chromatic chiaroscuro drawing in perspective }\end{array}$ & $\begin{array}{l}\text { Fine-tip, medium-tip or thick- } \\
\text { tip marker pens on paper. DIN } \\
\text { A4 and DIN A3. }\end{array}$ \\
\hline & & $\bullet$ & $\bullet$ & $\begin{array}{l}\text { 7D. Chromatic or monochromatic interpretation of the } \\
\text { practice } 7 \mathrm{C} \text { to represent its three-dimensional appearance } \\
\text { using flat inks. }\end{array}$ & $\begin{array}{l}\text { Marker pens, inks, watercolors } \\
\text { or watercolor pencils on paper. } \\
\text { DIN A4 or DIN A3. }\end{array}$ \\
\hline
\end{tabular}




\section{THE INTERNATIONAL JOURNAL OF DESIGN EDUCATION}

Group 8 was an analysis of everyday objects: vehicle. There were three practices to improve the observation of large industrial products and their representation with different techniques from different viewpoints (8A and $8 \mathrm{~B}$ ). On this occasion, besides insisting on the immediacy of the rapid sketch, students also proposed the design or redesign of a special vehicle for the beach to reinterpret the functional aspect of a conventional vehicle, applying it to another, more playful one $(8 \mathrm{C})$.

Table 8: Breakdown of Exercises (Group 8)

\begin{tabular}{|l|l|l|l|l|l|}
\hline \multicolumn{5}{|c|}{$\begin{array}{c}\text { Competences to Be } \\
\text { Achieved }\end{array}$} & \multicolumn{2}{|c|}{$\begin{array}{c}\text { Exercises to Achieve Competences: } \\
\text { Description and / or Procedure }\end{array}$} & Implemented Technique \\
\hline C1 & C2 & C3 & C4 & \multicolumn{1}{|c|}{} \\
\hline & & $\bullet$ & $\bullet$ & $\begin{array}{l}\text { 8A. Perspective line drawing of a vehicle (car or } \\
\text { motorbike) }\end{array}$ & $\begin{array}{l}\text { Ball pen on paper. Blue color. } \\
\text { DIN A4. }\end{array}$ \\
\hline & & $\bullet$ & $\bullet$ & $\begin{array}{l}\text { 8B. Drawing the object in chiaroscuro and perspective } \\
\text { (another point of view, different from that of practice 8A) }\end{array}$ & 2B pencil on paper. DIN A4. \\
\hline$\bullet$ & $\bullet$ & $\bullet$ & $\begin{array}{l}\text { 8C. Design or redesign of a children's beach vehicle, in } \\
\text { chiaroscuro, with preliminary sketches }\end{array}$ & $\begin{array}{l}\text { Free technique on paper. DIN } \\
\text { A4 or DIN A3. }\end{array}$ \\
\hline
\end{tabular}

Group 9 was an analysis of furniture (urban/domestic) and architecture. By means of four practices, the intention was that students, after having focused on the analysis and expression of furniture or lighting objects (9A and 9B), relate these household products to their spatial context, representing both as a single set (9C) and integrating a schematized human figure, to consider the importance of the scale and relationship of the human being with the architectural environment (9D). The concept of "graphic animation" was introduced, enhancing the visual expressiveness of the drawings through student's personal textures or tracings, avoiding representing the surfaces excessively blurred.

Table 9: Breakdown of Exercises (Group 9)

\begin{tabular}{|c|c|c|c|c|c|}
\hline \multicolumn{4}{|c|}{$\begin{array}{c}\text { Competences to Be } \\
\text { Achieved }\end{array}$} & \multirow{2}{*}{$\begin{array}{l}\text { Exercises to Achieve Competences: } \\
\text { Description and / or Procedure }\end{array}$} & \multirow{2}{*}{ Implemented Technique } \\
\hline C1 & $\mathrm{C} 2$ & $\mathbf{C 3}$ & $\mathrm{C} 4$ & & \\
\hline & & $\bullet$ & $\bullet$ & $\begin{array}{l}\text { 9A. Expressive sketching of an element of lighting or } \\
\text { furniture }\end{array}$ & $\begin{array}{l}\text { Ball pen and fine or medium- } \\
\text { tip marker pen. DIN A4. }\end{array}$ \\
\hline & & $\bullet$ & $\bullet$ & $\begin{array}{l}\text { 9B. Expressive sketching of an element of lighting or } \\
\text { furniture (a new point of view if it is the same object) }\end{array}$ & $\begin{array}{l}\text { Ball pen and fine or medium- } \\
\text { tip marker pen. DIN A4. }\end{array}$ \\
\hline & & $\bullet$ & • & $\begin{array}{l}\text { 9C. Representation of the same element of furniture or } \\
\text { lighting integrated in the architectural environment in } \\
\text { which it is located }\end{array}$ & $\begin{array}{l}\text { HB or } 2 \mathrm{~B} \text { pencil on paper. } \\
\text { DIN A4. }\end{array}$ \\
\hline & & $\bullet$ & $\bullet$ & $\begin{array}{l}\text { 9D. Free chromatic interpretation of practice 9C, } \\
\text { introducing the schematic image of a possible user }\end{array}$ & $\begin{array}{l}\text { Free technique on paper. DIN } \\
\text { A4. }\end{array}$ \\
\hline
\end{tabular}

Group 10 was designing a pet for an event or for a company. Through practice 10A, it was intended that the students learn to work as a team, sharing their ideas quickly through sketching and working collaboratively. 
FELIP AND NA VARRO: ENHANCING FREEHAND SKETCHING IN INDUSTRIAL DESIG|

Table 10: Breakdown of Exercises (Group 10)

\begin{tabular}{|c|c|c|c|c|c|}
\hline \multicolumn{4}{|c|}{$\begin{array}{c}\text { Competences to Be } \\
\text { Achieved }\end{array}$} & \multirow{2}{*}{$\begin{array}{c}\text { Exercises to Achieve Competences: } \\
\text { Description and / or Procedure }\end{array}$} & \multirow{2}{*}{ Implemented Technique } \\
\hline C1 & $\mathrm{C} 2$ & C3 & $\mathrm{C4}$ & & \\
\hline$\bullet$ & $\bullet$ & $\bullet$ & • & $\begin{array}{l}\text { 10A. Designing a pet for an event or for a company } \\
\text { (teamwork of three to four people). Set of linear and } \\
\text { expressive drawings that represent the shape and nature } \\
\text { of the character. }\end{array}$ & $\begin{array}{l}\text { Work in teams of three to four } \\
\text { people. Pencils, ballpensball } \\
\text { pens or fine-tip markers for } \\
\text { sketches. Free technique for } \\
\text { the presentation panel. DIN } \\
\text { A3. }\end{array}$ \\
\hline
\end{tabular}

Group 11 was resources to show ideas: presentations and digital mock-ups. Through practice $11 \mathrm{~A}$, students became familiar with the use of digital photo retouching tools, learning to integrate various pictures into one by modifying various parameters such as color, brightness, contrast, and saturation. Practice 11B allowed students to practice their oral communication skills by defending a personal portfolio.

Table 11: Breakdown of Exercises (Group 11)

\begin{tabular}{|c|c|c|c|c|c|}
\hline \multicolumn{4}{|c|}{$\begin{array}{c}\text { Competences to Be } \\
\text { Achieved }\end{array}$} & \multirow{2}{*}{$\begin{array}{c}\text { Exercises to Achieve Competences: } \\
\text { Description and / or Procedure }\end{array}$} & \multirow{2}{*}{ Implemented Technique } \\
\hline C1 & $\mathrm{C2}$ & C3 & C4 & & \\
\hline & $\bullet$ & $\bullet$ & $\bullet$ & 11A. Integration of images in different pictures & $\begin{array}{l}\text { Digital image retouching. } \\
\text { Recommended software: } \\
\text { Adobe Photoshop, Gimp. }\end{array}$ \\
\hline$\bullet$ & $\bullet$ & & $\bullet$ & $\begin{array}{l}\text { 11B. Individual presentation of the personal portfolio of } \\
\text { the course or other personal artistic and graphic creations } \\
\text { (maximum three minutes). The presentation should show } \\
\text { only a selection of the most satisfactory works, whether } \\
\text { of the current course, the previous course or non- } \\
\text { academic personal works. }\end{array}$ & $\begin{array}{l}\text { Microsoft } \\
\text { PowerpointPowerPoint or } \\
\text { Apache OpenOffice Impress. }\end{array}$ \\
\hline
\end{tabular}

Group 12 was abstraction and formal synthesis. Through eleven individual exercises, students should have developed the ability to imagine different creative solutions based on proposals related to abstraction, synthesis, and formal schematization of objects. 
Table 12: Breakdown of Exercises (Group 12)

\begin{tabular}{|c|c|c|c|c|c|}
\hline \multicolumn{4}{|c|}{$\begin{array}{l}\text { Competences to Be } \\
\text { Achieved }\end{array}$} & \multirow{2}{*}{$\begin{array}{l}\text { Exercises to Achieve Competences: } \\
\text { Description and / or Procedure }\end{array}$} & \multirow{2}{*}{$\begin{array}{l}\text { Implemented } \\
\text { Technique }\end{array}$} \\
\hline C1 & $\mathrm{C2}$ & $\mathrm{C} 3$ & C4 & & \\
\hline • & & • & & $\begin{array}{l}\text { 12A. Static visual retention exercises: After projecting the } \\
\text { static image of an object for one minute, remember it and draw } \\
\text { it without seeing it. }\end{array}$ & $\begin{array}{l}\text { Ball pen on paper. DIN } \\
\text { A4. }\end{array}$ \\
\hline$\bullet$ & & $\bullet$ & & $\begin{array}{l}\text { 12B. Dynamic visual retention exercises (1): After viewing for } \\
\text { one minute the projection of the image of an object shown } \\
\text { rotating in a loop, draw it from memory. }\end{array}$ & $\begin{array}{l}\text { HB or } 2 \mathrm{~B} \text { pencil on } \\
\text { paper. DIN A4. }\end{array}$ \\
\hline • & & $\bullet$ & & $\begin{array}{l}12 \mathrm{C} \text {. Dynamic visual retention exercises }(1) \text { : Draw an object } \\
\text { shown rotating in a loop considering the structure and shape, } \\
\text { highlighting or enhancing the tridimensionality by } \\
\text { chiaroscuro. }\end{array}$ & $\begin{array}{l}\text { Ball pen on paper. } \\
\text { DIN A4. }\end{array}$ \\
\hline$\bullet$ & & $\bullet$ & & $\begin{array}{l}\text { 12D. Spatial restitution exercise. Draw an object in perspective } \\
\text { starting from the vision of four pictures in orthogonal position. }\end{array}$ & $\begin{array}{l}\text { Ball pen on paper. } \\
\text { DIN A4. }\end{array}$ \\
\hline$\bullet$ & & • & & $\begin{array}{l}\text { 12E. Exercise of conceptualization and use of the line. Select } \\
\text { one of the six images offered and interpret it in a single stroke } \\
\text { without lifting the pen from the paper. }\end{array}$ & $\begin{array}{l}\text { Ball pen on paper. } \\
\text { DIN A4. }\end{array}$ \\
\hline$\bullet$ & & $\bullet$ & & $\begin{array}{l}\text { 12F. Exercise of conceptualization and constructive synthesis. } \\
\text { Select one of the six images that are offered and interpret it by } \\
\text { drawing the structure, showing the apparent volume of the } \\
\text { object. }\end{array}$ & $\begin{array}{l}\text { HB or } 2 \mathrm{~B} \text { pencil, ball } \\
\text { pen or fine-tip marker on } \\
\text { paper. DIN A4. }\end{array}$ \\
\hline$\bullet$ & & • & & $\begin{array}{l}\text { 12G. Iconic synthesis and conceptualization exercise } \\
\text { (infantilization). Select one of the six images offered and } \\
\text { interpret it as a more childlike image of the object, in order to } \\
\text { be used for the design of a child product (coloring page, } \\
\text { clothing image, graphic design or toy). }\end{array}$ & $\begin{array}{l}\text { BallpenBall pen or fine- } \\
\text { tip marker on paper. } \\
\text { DIN A4. }\end{array}$ \\
\hline$\bullet$ & & $\bullet$ & & $\begin{array}{l}\text { 12H. Exercise of conceptualization and iconic synthesis } \\
\text { (iconicity). Select one of the six images offered and interpret it } \\
\text { in a simplified form to be used as a logo or trademark of a } \\
\text { company, institution or event. }\end{array}$ & $\begin{array}{l}\text { HB or } 2 B \text { pencil, } \\
\text { ballpenball pen or fine- } \\
\text { tip marker on paper. } \\
\text { DIN A4. }\end{array}$ \\
\hline$\bullet$ & & $\bullet$ & & $\begin{array}{l}\text { 12I. Conceptualization and synthesis exercise } \\
\text { (polyhedrization). Each student will interpret the volume of a } \\
\text { human head by line and chiaroscuro, using geometric planes, } \\
\text { trying to generate a polyhedral vision of the head's basic } \\
\text { shape. The model to be drawn will be a classmate and, in a } \\
\text { second phase, that classmate will draw the student's head in } \\
\text { the same way. }\end{array}$ & $\begin{array}{l}\text { BallpenBall pen on } \\
\text { paper. } \\
\text { DIN A4. }\end{array}$ \\
\hline$\bullet$ & & • & & $\begin{array}{l}\text { 12J. Conceptualization and synthesis exercise } \\
\text { (caricaturization). Each student will interpret the image of a } \\
\text { person's face through the exaggeration of traits or } \\
\text { caricaturization, trying to generate a recognizable image of the } \\
\text { portrayed / caricatured. The model to be drawn will be a } \\
\text { classmate and, in a second phase, that classmate will draw the } \\
\text { student in the same way. }\end{array}$ & $\begin{array}{l}\text { HB or } 2 \text { B pencil on } \\
\text { paper. DIN A4. }\end{array}$ \\
\hline$\bullet$ & & - & & $\begin{array}{l}12 \mathrm{~K} \text {. Exercise of conceptualization and transformation } \\
\text { synthesis (metamorphosis). Interpret the metamorphosis } \\
\text { between two different objects. At least three sequential } \\
\text { drawings of transformation must be made between the two } \\
\text { different forms of objects, considering the initial object (thin } \\
\text { brush), the intermediate object (thick brush) and the final } \\
\text { object (broom). }\end{array}$ & $\begin{array}{l}\text { HB or } 2 \mathrm{~B} \text { pencil on } \\
\text { paper. DIN A4. }\end{array}$ \\
\hline
\end{tabular}


Group 13 was the design project: design of an element of furniture or lighting. Through practice 13A, a graphic composition of various elements in a space was proposed, and students learned to distribute them with the intention of creating a narrative discourse of visual nature.

Table 13: Breakdown of Exercises (Group 13)

\begin{tabular}{|c|c|c|c|l|l|}
\hline \multicolumn{3}{|c|}{$\begin{array}{c}\text { Competences to Be } \\
\text { Achieved }\end{array}$} & \multicolumn{2}{|c|}{$\begin{array}{c}\text { Exercises to Achieve Competences: } \\
\text { Description and / or Procedure }\end{array}$} & Implemented Technique \\
\hline C1 & $\mathbf{C 2}$ & $\mathbf{C 3}$ & $\mathbf{C 4}$ & & \\
\hline & $\bullet$ & $\bullet$ & $\bullet$ & $\begin{array}{l}\text { 13A. Furniture design project according to five different } \\
\text { product alternatives. Representation of the design } \\
\text { through a visual panel that includes several previous } \\
\text { conceptual sketches, orthogonal projections with basic } \\
\text { dimensions, elementary specifications of the product and } \\
\text { a color render of the final design. }\end{array}$ & $\begin{array}{l}\text { Various techniques. Digital } \\
\text { mock-up. DIN A3. }\end{array}$ \\
\hline
\end{tabular}

\section{Objective Assessment by Rubrics}

Some rubrics were created for evaluating the different aspects of each exercise, with a triple objective: to guide the teacher towards a more unbiased, objective and homogenous assessment system; to inform the students of the criteria with which they will be evaluated, being able to detect their own shortcomings more effectively and learning to solve them; and inform students them [students?] of the level to reach to acquire the necessary skills. Each rubric specified the various aspects to be evaluated and the criteria for assessing each of them. All the exercises were self-evaluated by the students using these rubrics, acquiring objective criteria throughout the course with which to evaluate their work in an impartial way. Deciding the final mark was the responsibility of the teachers, evaluating according to the same criteria of the rubric: fitting and proportion, technique of expression, lines and expressivity, perspective, treatment of chiaroscuro, and three-dimensional expression and interpretation. 


\begin{tabular}{|c|c|c|c|c|c|c|c|c|c|c|c|c|}
\hline & & & & & & XE & E SEL & $=-E V A L$ & & & & \\
\hline & Criteria & & $Y P$ & & & $\mathrm{OOC}$ & & & & & $R R$ & \\
\hline 㟛 & $\begin{array}{l}\text { Fitting \& } \\
\text { proportion } \\
\text { (adaptation }\end{array}$ & & $\begin{array}{l}\text { prett } \\
\text { d th } \\
\text { ispre }\end{array}$ & $\begin{array}{l}\text { in all } \\
\text { etoo } \\
\text { ons }\end{array}$ & The & норе & $\begin{array}{l}\text { cases } \\
\text { ny }\end{array}$ & $\begin{array}{l}\text { The fit } \\
\text { but }\end{array}$ & $\begin{array}{l}\text { ely well, } \\
\text { ome } \\
\text { ns }\end{array}$ & & $\begin{array}{l}\text { here } \\
\text { ropo }\end{array}$ & ases \\
\hline 离 & $\begin{array}{l}\text { and visual } \\
\text { expression) }\end{array}$ & 0 & 1 & 2 & 3 & 4 & 5 & 6 & 7 & 8 & 9 & 10 \\
\hline $\begin{array}{l}\frac{2}{w} \\
\text { 岂 } \\
\alpha\end{array}$ & $\begin{array}{l}\text { Expression } \\
\text { technique }\end{array}$ & The & $\begin{array}{l}n \text { ne } \\
\text { lly ar }\end{array}$ & $\begin{array}{l}d \text { has } \\
\text { in }\end{array}$ & $\begin{array}{l}\text { The } \\
\text { not t }\end{array}$ & $\begin{array}{l}\text { vell } \\
\text { cas }\end{array}$ & $\begin{array}{l}\text { has } \\
\text { some }\end{array}$ & $\begin{array}{l}\text { The ter } \\
\text { been }\end{array}$ & $\begin{array}{l}\text { lied has } \\
\text { n most }\end{array}$ & $\begin{array}{l}\text { The } \\
\text { been }\end{array}$ & used & $\begin{array}{l}\text { d has } \\
\text { cases }\end{array}$ \\
\hline 离 & & 0 & 1 & 2 & 3 & 4 & 5 & 6 & 7 & 8 & 9 & 10 \\
\hline & Line layout & & $\begin{array}{l}\text { Straw } \\
\text { errat } \\
\text { certa } \\
\text { case }\end{array}$ & $\begin{array}{l}\text { quite } \\
\text { inith } \\
\text { in all }\end{array}$ & $\begin{array}{l}\text { The } \\
\text { and }\end{array}$ & ny & $\begin{array}{l}\text { egular } \\
\text { ainties }\end{array}$ & $\begin{array}{l}\text { The lin } \\
\text { but with }\end{array}$ & $\begin{array}{l}\text { correct, } \\
\text { ertainties } \\
\text { es }\end{array}$ & & $\begin{array}{l}\text { y reg } \\
\text { case }\end{array}$ & clean \\
\hline$\frac{\mathrm{O}}{\frac{1}{4}}$ & & 0 & 1 & 2 & 3 & 4 & 5 & 6 & 7 & 8 & 9 & 10 \\
\hline 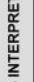 & Perspective & & ect & & $\begin{array}{l}\text { The } \\
\text { exp } \\
\text { inco }\end{array}$ & $\begin{array}{l}\text { ecti } \\
\text { on e } \\
\text { nt in }\end{array}$ & $\begin{array}{l}d \text { has } \\
\text { nd is } \\
\text { cases }\end{array}$ & $\begin{array}{l}\text { The pe } \\
\text { hard } \\
\text { errors } \\
\text { at }\end{array}$ & $\begin{array}{l}\text { sed has } \\
\text { ession } \\
\text { istent in } \\
\text { ses }\end{array}$ & $\begin{array}{l}\text { The } \\
\text { no ex } \\
\text { co }\end{array}$ & ion & $\begin{array}{l}d \text { has } \\
\text { and is } \\
\text { ses }\end{array}$ \\
\hline zo & & 0 & 1 & 2 & 3 & 4 & 5 & 6 & 7 & 8 & 9 & 10 \\
\hline 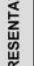 & $\begin{array}{l}\text { Treatment of } \\
\text { chiaroscuro }\end{array}$ & & ve in & $\begin{array}{l}\text { ent is } \\
\text { ses }\end{array}$ & & in & $\begin{array}{l}\text { ent is } \\
\text { ases }\end{array}$ & $\begin{array}{l}\text { Chiar } \\
\text { effec }\end{array}$ & $\begin{array}{l}\text { ment is } \\
\text { some }\end{array}$ & & $e$ in & $\begin{array}{l}\text { nt is } \\
\text { es }\end{array}$ \\
\hline 产 & & 0 & 1 & 2 & 3 & 4 & 5 & 6 & 7 & 8 & 9 & 10 \\
\hline 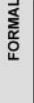 & $\begin{array}{l}\text { Expression } \\
\text { and } \\
\text { interpretation } \\
\text { (3D) }\end{array}$ & $\begin{array}{r}\text { The } \\
\text { sh } \\
\text { din } \\
\text { gen }\end{array}$ & сpres & $\begin{array}{l}\text { es not } \\
\text { ree- } \\
\text { the } \\
\text { s bad }\end{array}$ & & regu & $\begin{array}{l}\text { nows } \\
\text { ree- } \\
\text { the } \\
n \text { is }\end{array}$ & $\begin{array}{l}\text { The in } \\
\text { enou } \\
\text { dime } \\
\text { genera }\end{array}$ & $\begin{array}{l}\text { shows } \\
\text { three- } \\
\text { nd the } \\
\text { is quite }\end{array}$ & $\begin{array}{r}\text { The } \\
\text { gr } \\
\text { din } \\
\text { gene }\end{array}$ & goo & $\begin{array}{l}\text { ows a } \\
\text { ee- } \\
\text { the } \\
\text { very }\end{array}$ \\
\hline & & 0 & 1 & 2 & 3 & 4 & 5 & 6 & 7 & 8 & 9 & 10 \\
\hline
\end{tabular}

$$
\text { FINAL MARK }=\frac{\text { Sum of all the criteria }}{\text { number of assessed criteria }}=
$$

Figure 3: Example of One of the Rubrics Designed to Evaluate the Third Group of Exercises (3A-3D) Source: Felip and Navarro 2018

\section{Results}

\section{Observable Results in Each Group of Exercises}

The data obtained after the application of this way of working allows us to speak of positive results in general terms. It is therefore possible to affirm that the methodology implemented has helped the students in most cases to acquire the skills of the subject. The results of the thirteen exercise groups are described in detail below and some observations are made.

Group 1: In the practices carried out, the students reached an average mark of 6.24 points out of 10. It is observed that after four months of inactivity without drawing since the subject "Artistic Expression I," the ability of visual analysis and agility in graphic expression is diminished. The results obtained show a high number of students that exceed 5 points $(90.59 \%)$, with 9 points being the highest mark and 2 points being the lowest.

Group 2: On this occasion, an average mark of 6.36 points was obtained, similar to that obtained in group 1 . The exercises were passed by 92.94 percent of students, with a highest mark of 8.5 points and a lowest mark of 3 points. It is observed that students have difficulties understanding the proposals for experimentation and conceptual expression. The students do not understand the need to interpret the visible objects instead of copying them through mere 
photographs. Although it was observed that most students draw very slowly because they are still afraid of making mistakes, they are slowly gaining confidence in their skills.

Group 3: In this group of practices, an average mark of 6.65 points was obtained. Of all the students, 94.12 percent of the students exceeded 5 points, an improvement that reflects a recovery of the skills acquired in the previous semester with the subject "Artistic Expression I." The highest mark is 9.5 points, and the lowest mark is 1 point. A greater confidence in the development of exercises compared to initiation practices 1 and 2 is observed.

Group 4: An average mark of 6.84 points was obtained, with 9.5 points as the highest mark and 5 points as the lowest. Of the students-who did the exereises, 100 percent passed thl exercises of the students who passed them, which indicates the acquisition of greater agility to use the techniques proposed. There were only two students who did not submit the paperswork. I general terms, it is observed that there are still some questions concerning the free interpretation that they find it difficult to assimilate as an effective means of representation In general terms, t is observed that students still have difficulties interpreting graphically what they don't see, because they are accustomed to drawing only what they can see.

[This sentence is unclear; please revise it and/or break it into multiple sentences.]

Group 5: In the practices of group 5, an average mark of 6.98 points was obtained, with 9.4 points being the highest mark and 2 points the lowest. Of the students, 96.47 percent exceeded 5 points, and the average quality of the work began to be more than acceptable, although students still had difficulties simplifying and reducing the amount of visual information of the observed objects.

Group 6: For group 6, an average mark of 7.32 points was obtained. Of the students, 95.29 percent exceeded 5 points. The highest mark was 9.4 points, and the lowest mark was 1 point. There was a great improvement in the ability to draw and conceptualize the visible shapes, showing more precise strokes.

Group 7: The students achieved an average mark of 7.08 points. Of the students, 94.12 percent exceeded 5 points, with 9.5 points being the highest mark and 2 points the lowest. In previous courses, practices 5, 6, and 7 used very similar models, and this made the students become bored and lose interest in the exercise. In the present course, more varied models have been used for these practices, which has increased the motivation of the students to face these tasks.

Group 8: In the exercises of group 8, an average mark of 6.62 points was obtained. Of the students, 87.06 percent exceeded 5 points. The highest mark is 9.5 points, and the lowest mark is 3.5 points. It is observed that at first, they were not able to interpret the proportions from their point of view, drawing in a more conceptual way and with greater disproportions. They also felt uncomfortable taking field notes outside the classroom because they are not accustomed to drawing on a support surface less stable than a table.

Group 9. In group 9, an average mark of 6.23 points was obtained. Of the students, 88.24 percent exceeded 5 points, with 9 points being the highest mark and 2.5 points the lowest. It was observed that the architectural theme was more difficult for most students, who were not prepared to represent the interior space intuitively because they are more accustomed to drawing objects. However, the incursion into a theme of these characteristics allowed them to practice the synthesis of the elements represented, with a consequent improvement of their way of expressing space.

Group 10: This group was the best assessed of the subject, with an average mark of 7.92 points, 9 points being the highest mark and 5 points the lowest. All the students who have presented the works of this group have passed them. The evaluation of the works is done jointly (the students evaluate each other), and it is verified that they are quite critical and objective in their assessments.

Group 11. An average mark of 7.49 points was obtained. Of the students, 94.12 percent exceeded 5 points, with 8.3 points as the highest mark. The exercises of group 11 showed that 
very few students deal well with image processing software. Except for a few students, most of them are-were motivated and strived for a good result. It was also observed that most of the students felt uncomfortable in the oral public presentation of their portfolio, probably because it was the first time in the degree, although the experience was interesting and enriching for them.

Group 12: This group was passed by 92.94 percent of students, registering an average mark of 6.50 points, with 9.7 points as the highest mark and 1 point as the lowest. Since these exercises are very diverse, there is a strong variation of marks between the exercises of each student, although the average mark of the class is similar to that of the other groups of exercises.

Group 13: Finally, in this group of exercises, students got an average mark of 6.82 points, with the highest mark being 9.8 points. All the students who presented this group of exercises managed to exceed 5 points. Although in this course the project and the methodology were presented earlier (so the students had more time to develop it and the teachers had more time to follow up), it was detected that most students carried out this project without having consulted the teachers sufficiently to resolve formal, technical, and representation issues. It is very likely that this situation was due to overconfidence in the acquired skills and to the accumulation of deliverables of other subjects, which made the students accelerate the completion of the work and neglect important aspects. 

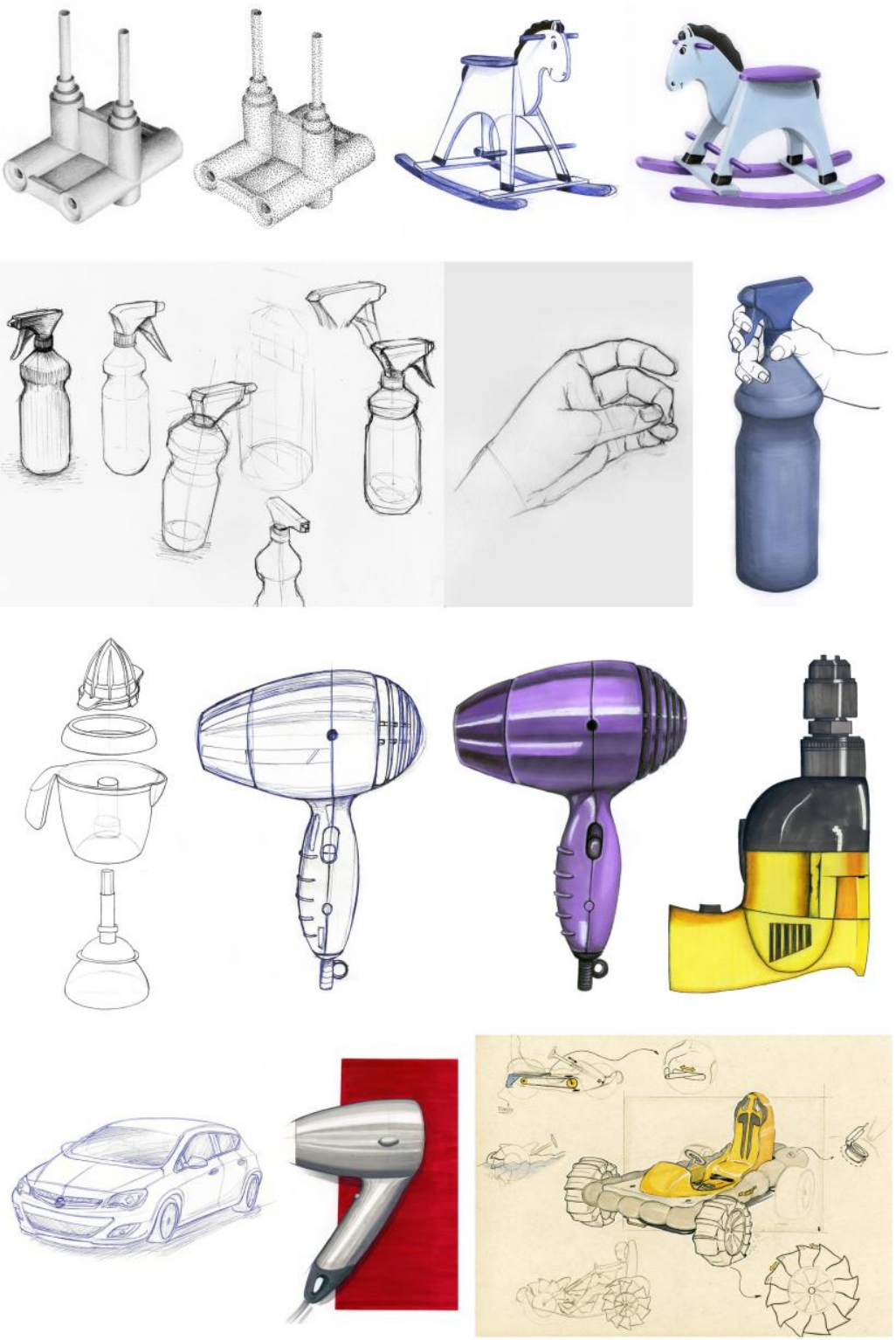

Figure 4: Examples of Graphic Exercises Developed by Students. First row: 1E and 1F (Paula Bañuelos Cid), 3C (Sergio Ramón Lucea), and 3D (Andrea Pérez Albiol); second row: 5A (Artur Korenkov), 5B (Noelia Ortega Lozano), and 5D (Andrea Pérez Albiol); third row: 6B (Cristina Martí Monferrer), 6C and 6D (Andrea Pérez Albiol) and 6D (Malu Tataje Cruces); fourth row: 8A and 8B (Jose Manuel Palacios Garcia) and 8C (Sergio Ramón Lucea).

$$
\text { Source: Felip and Navarro } 2018
$$




\section{THE INTERNATHONAL JOURNAL OF DESIGN EDUCATION}

\section{Self-Evaluation of Students}

At the end of the course, the students had to answer a survey. They were asked if they believed they had improved their skills in analysis and expression through drawing, comparing the knowledge they had acquired at the end of the course with that they had at the beginning. Eightyone of the eighty-five students enrolled answered the survey, forty-eight of whom said they had improved their skills and thirty-three of whom said they did not consider themselves to have improved (Figure 5).
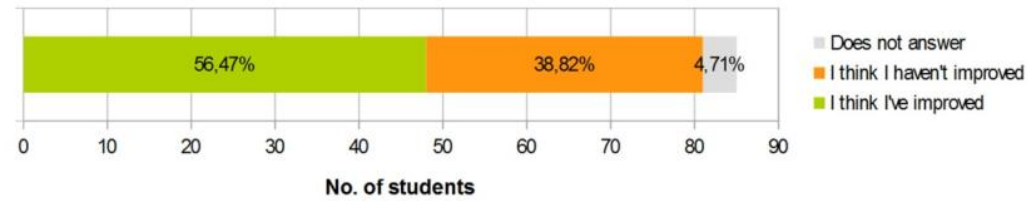

Figure 5: Perception of Students on the Improvement of Their Skills at the End of the Course Source: Felip and Navarro 2018

The students also assessed objectively the ability of graphic expression that they believed to have reached at the end of the course, assessing globally their skill, the visual quality of their works, and the adequacy of the strokes employed. The students' average self-assessment of their own skills was 7.41 points out of 10 , similar to the real average mark achieved in the course. Given that during the course they were not informed of the numerical marks that they were obtaining in the exercises, only if their work was going well or not, it is possible to affirm, on the one hand, that the students have acquired the capacity to assess their own work according to objective criteria and, on the other hand, that the proposed rubrics are complete enough to allow the acquisition of those criteria.

\section{Overall Results and Performance}

The high attendance throughout the course confirmed the existence of a high interest of the students in this subject, as predicted the answers to the second question of the initial survey. All the students who regularly attended the course and submitted the papers were able to pass, which reveals that both the number of exercises and their distribution throughout the course were adequate for their correct follow-up by most students. Eighty-two of the eighty-five students enrolled succeeded in passing the subject in the first round $(96.47 \%)$. The only three students who could not pass the subject were because they stopped attending classes and did not present some of the works. The percentage of students who passed each exercise group was very high (Figure 6). Similarly, it is possible to corroborate that the level of difficulty of each exercise was appropriate, since the high marks obtained by some students confirm that it is possible to obtain the maximum qualification, or at least approach it (Figure 7). 
FELIP AND NAVARRO: ENHANCING FREEHAND SKETCHHG IN INDUSTRIAL DESIG|

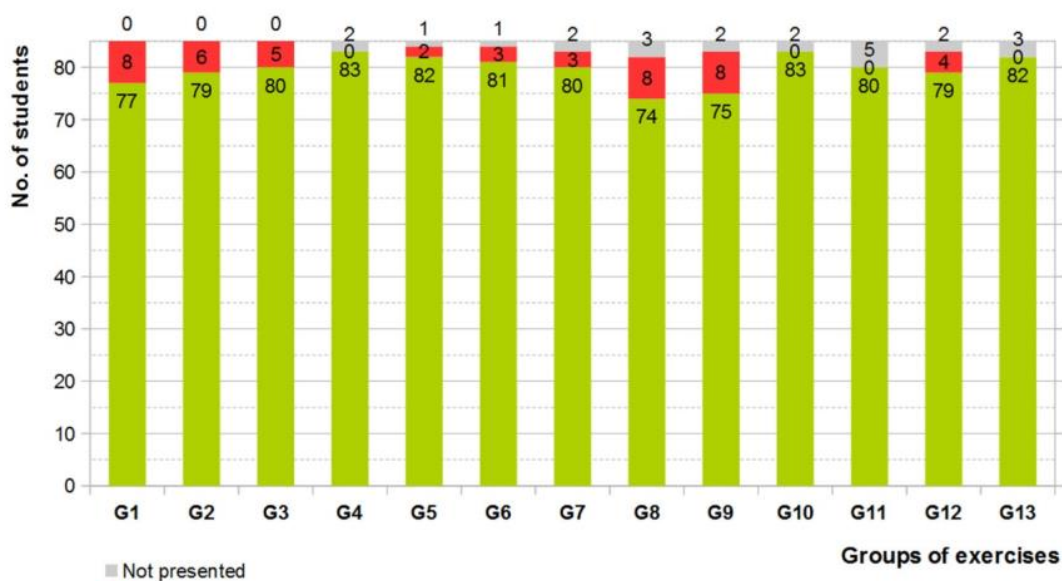

Not passed

Inassed

Figure 6: The Number of Students Passed, Not Passed, and Not Presented in Each Group of Exercises Source: Felip and Navarro 2018

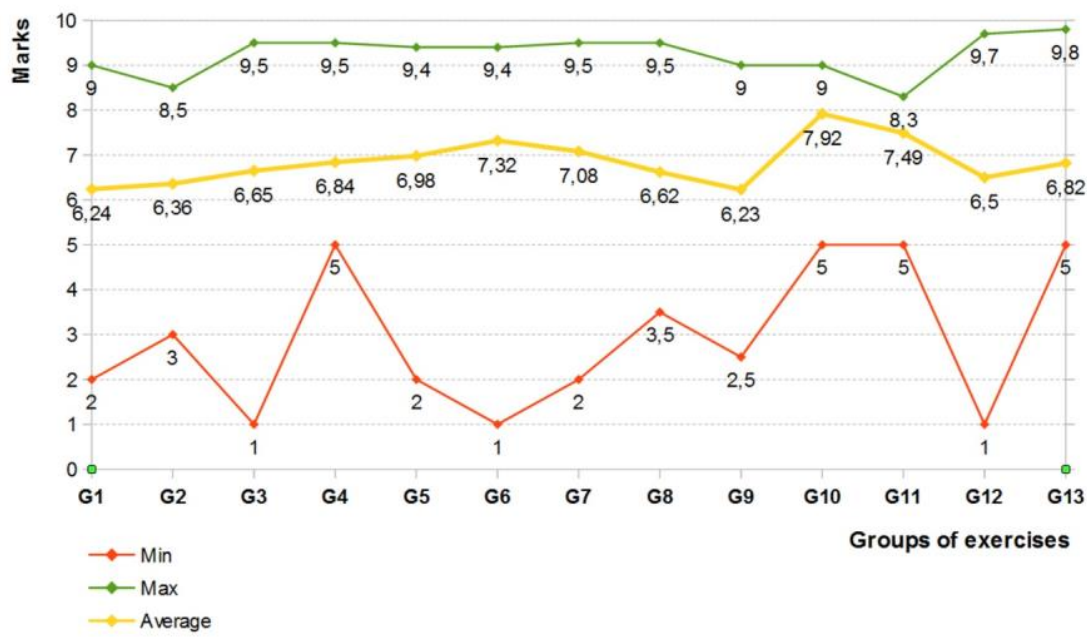

Figure 7: Minimum, Average, and Maximum Marks for Each Group of Exercises Source: Felip and Navarro 2018

Finally, the average mark of all exercises was 7.0 points out of 10 (Figure 8). This fact, together with the high percentage of students who succeeded in passing the subject, can corroborate in general terms a correct acquisition of competences. 


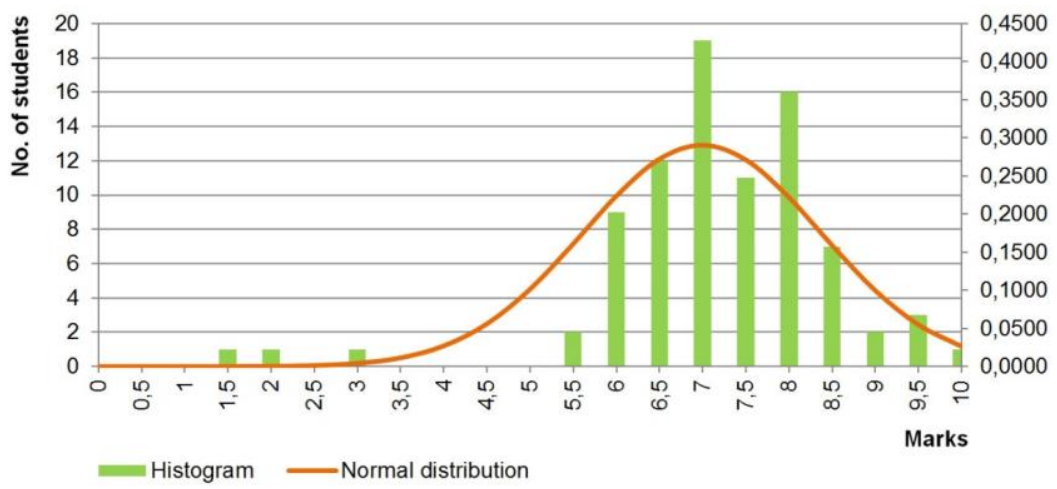

Figure 8: Normal Distribution of the Final Marks in the First Round of the Subject Average: 7.0; Standard Deviation: 1.373 Source: Felip and Navarro 2018

\section{Conclusions and Discussion}

Considering the grades and results obtained, it is possible to affirm that the methodology implemented in the subject has had a positive impact on the students. Research questions Q1 and Q2 are answered affirmatively and, therefore, hypotheses $\mathrm{H} 1$ and $\mathrm{H} 2$ are hereby confirmed:

- Habituating students to observe familiar industrial products as well as manipulating and experimenting them in a tactile manner have proven to be effective in getting students familiar with their various formal proportions and spatial features. This has helped them generate mental images closer to objectual reality, making it easier for them to represent similar products during the conceptual design process, even if they do not have a physical model in sight. Q1 is therefore answered affirmatively, and so H1 holds.

- Similarly, becoming familiar with the various drawing tools and manual techniques for quick representation has helped students to know and understand the expressive possibilities of the different graphic languages used by industrial designers, helping them to choose the most appropriate in each occasion. Q2 is therefore answered affirmatively, and so $\mathrm{H} 2$ holds.

- Finally, dealing with a wide variety of representation exercises working in different ways, has helped students to be more versatile, think in different ways, and practice different strategies to solve the problems raised, improving their creativity.

The exercises and their sequencing during the course have allowed almost all students to achieve the competences satisfactorily. It should be mentioned that the students who did not pass the course did not attend class and did not finish some of the exercises. Therefore, it is possible to say that the proposed methodology allows all the students who regularly attend classes to reach the skills of the subject, regardless of whether their previous training is more or less technical.

Although the average marks obtained in all exercise groups have been satisfactory, they could still be improved. The lower average mark in some exercises may have been due to overwork in other subjects. This could have prevented students from spending more time working on these exercises, and could be the cause of lower performance. One of the possible reasons that the average mark was not more homogeneous in all the exercises can be the 
coincidence between the delivery dates of some exercises with other delivery dates in other subjects, that can make the students do not have enough time to work properly and consequently decrease their performance. [This sentence is unclear; please revise it.]-If this methodology continues to be applied in the following courses, it is advisable to monitor it and adjust the schedule of activities, if necessary.

To verify if the competences acquired in this subject have had any repercussion in other related subjects of the second year of the degree, a series of observations have been carried out in the subjects taught during the following months. In the second semester, it was observed that in these subjects the students of this course drew more easily than the students of previous courses, representing the ideas about new products in a more agile, faster way and with greater skill. It was observed, however, that as time passed the students repeated some of their old mistakes or repeatedly used the techniques of graphic representation that they used before the subject, not daring to continue using the new ones they learned that would give them a richer and varied visual result, returning instead to old ways of working, which were more comfortable but more limited. This result is similar to that obtained in other study, which mentioned that the skills obtained after practicing freehand sketching for a few months were effective in the short term but diminished over time if they were not continued to practice (Booth et al. 2016). Therefore, it would be advisable to keep a supervision of the students' work in these other subjects to continue applying the freehand sketching during any design process.

The results of this course are promising in the short term. Therefore, the methodology presented seems to be adequate to help industrial design students improve the use of freehand sketching. However, it is advisable to carry out a more detailed follow-up to verify if the skills supposedly acquired through the implementation of this methodology are also maintained in the subjects of following years, to detect possible aspects that can be improved and quantify the long-term impact that this methodology may have on how to approach professional projects once the degree has been completed.

\section{Acknowledgement}

The methodologies conducted in this subject are part of the educational improvement project with reference 3204/16, which has received funding from the Educational Support Unit of Jaume I University Universitat Jaume I through the annual program "Aids for Educational Innovation Projects at Jaume I University Universitat Jaume I in the 2016/17 course."

\section{REFERENCES}

Booth, Joran W., Elkin A. Taborda, Karthik Ramani, and Tahira Reid. 2016. "Interventions for Teaching Sketching Skills and Reducing Inhibition for Novice Engineering Designers." Design Studies 43: 1-23. http://doi.org/10.1016/j.destud.2015.11.002.

Carnevale, Valeria. 2015 “"To Design' or 'To Draw': Two Different Verbs, Two Different Abilities, One Result." The International Journal of Designed Objects 8 (1): 17-25. http://doi.org/10.18848/2325-1379/CGP/v08i01/38695.

Dong, Hua, Abdusselam Selami Cifter, and Zhong Fan. 2013. "Methods for Improving Undergraduate Students' Sketching Skills." International Journal of Mechanical Engineering Education 41 (4): 329-36. http://doi.org/10.7227/IJMEE.41.4.7.

Eggermont, Marjan J., D. M. Douglas, D. J. Caswell, and Clifton R. Johnston. 2004. "Back to the Future: Engineering Sketching as Visualization, Idea Generation and Communication Tool." In Proceedings of the Canadian Design Engineering Network Conference, edited by Canadian Engineering Education Association[name(s) of editor(s)], 1-7. Montreal: CEEA. http://doi.org/10.24908/pceea.v0i0.4038 


\section{THE INTERNATIONAL JOURNAL OF DESIGN EDUCATION}

Goldschmidt, Gabriela. 1991. "The Dialectics of Sketching." Creativity Research Journal 4 (2): 123-43. http://doi.org/10.1080/10400419109534381

Herbert, Daniel M. 1988. "Study Drawings in Architectural Design: Their Properties as a Graphic Medium." Journal of Architectural Education 41 (2): 26-38. http://doi.org/10.1080/10464883.1988.10758473.

Laseau, Paul. 2001. Graphic Thinking for Architects and Designers. New York: John Wiley \& Sons.

Travis, Stephanie. 2014. "Sketching as a Tool for Seeing: A Method for Teaching Drawing to Architecture and Interior Design Students." The International Journal of Design Education 7 (3): 63-74. http://doi.org/10.18848/2325-128X/CGP/v07i03/38452

Ullman, David G., Stephen Wood, and David Craig. 1990. "The Importance of Drawing in the Mechanical Design Process." Computer \& Graphics 14 (2): 263-74. http://doi.org/10.1016/0097-8493(90)90037-X.

Yang, Marla C., and Jorge G. Cham. 2007. "An Analysis of Sketching Skill and Its Role in Early Stage Engineering Design.” Journal of Mechanical Design 129 (5): 476-82. http://doi.org/10.1115/1.2712214.

\section{ABOUT THE AUTHORS}

Francisco Felip: Assistant Professor, Department of Industrial Systems Engineering and Design, Jaume I UniversityUniversitat Jaume I, Castellón de la Plana, Spain

José Luis Navarro: Professor, Department of Industrial Systems Engineering and Design, Jaume IUniversity Universitat Jaume I, Castellón de la Plana, Spain 